\title{
Exploring manager-subordinate dyads: The moderating effect of supervisory sup- port on the relationship between work locus of control and job involvement
}

\author{
Christopher G. Nunns* and Loukia Argirys \\ Department of Psychology, University of the Witwatersrand, P.0. Wits 2050, Republic of South Africa
}

Received 30 September 1991; accepled 19 February 1992

\begin{abstract}
In this article the modaraing effect of supervisory support on the relationship between work locus of control and job involvement is investigated. Seventy non-managerial banking employees constituted the sample. Using the statistical technique of Moderated Multiple Regression, results indicated that high supervisory support enhances job involvement of employees with an extemal locus of control orientation. High supervisory support was found to inhibit job involvement of employees with an internal locus of control orientation. Limitations of the results are discussed, as are implications for leadership research and practice.
\end{abstract}

\begin{abstract}
In hierdie artikel is ondersoek ingestel na die modererende effek van loesighoudende ondersteuning op die verhouding tussen lokus van kontrole in werksverband, en werksbetrokkenheid. Die steekproef het bestaan uit sewentig werknemers in die bankbedryf, onder bestuursvlak. Resultate van die statistiese tegniek 'Modererende Veelvuldige Regressie', het aangetoon hoe toesighoudende ondersteuning werknemers met 'n eksterne lokus van kontrole se werksbetrokkenheid verhoog. Daar is egter ook bevind dat loesighoudende ondersteuning die werksbetrokkenheid van werknemers met 'n interne lokus van kontrole, inperk. Beperkinge van die resultate word bespreek, asook die implikasies van leierskap in die praktyk en vir toekomstige navorsing op die gebied.
\end{abstract}

"To whom correspondence should be addressed.

Considering the overall job satisfaction of the British constabulary, Gilbert and Sullivan (1879) state that, 'the policeman's lot is not a happy one'. Indeed, the same can frequently be said of the South African manager. Pressurised from above for greater productivity and from below for better wages and working conditions, the manager has an unenviable task. Research into the intricacies of managerial leadership in South African organizations represent one way to attermpt to alleviate this situation.

Leadership has been described as one of the most observed, yet least understood phenomena in existence (COgill, 1986). However, effective leadership is a key factor for the successful functioning of an organization (Cogill, 1986; Vroom, 1983). Poor leadership is often given as a reason for inadequate organizational performance, and effective leadership for numerous organizational successes (Cogill, 1986). Indeed, Vroom contends that

'Any knowledge which the behavioral sciences can contribute to the aid in the identification and enhancement of leadership in organized human endeavour would be of immense societal value' (1983: 1528).

Consequenuly a good understanding of the phenomenon of leadership is ultimately of great importance to enhanced organizational functioning at the micro-level, and sustained enhanced economic growth at the macro-level. The critical shortage of managerial personnel in the South African industrial environment (see Chalmers, 1986) provides strong theoretical and practical justification for pursuing new and improved approaches towards organizational leadership within South Africa.

A new and promising approach to leadership study is George Graen's Leader-Member-Exchange (LMX) theory (Dienesch \& Liden, 1986; Vecchio, 1985). Indeed, a measuring instrument designed for the LMX model was found to be psychometrically satisfactory for two South African middle manager samples $(N$ 's $=243 \& 181)$ and one sample ( $\mathbf{N}=54$ ) of Black, South African industrial workers (Nunns, Ballantine, Burns, \& King, 1990). An interesting aspect of this approach is that the LMX theory stresses the importance of focusing on the individual dyadic relationships between supervisors or managers (termed 'leaders'), and each of their subordinates (termed 'mem. bers') (Vecchio \& Gobdel, 1984). Thus, in terms of this approach, the unit of analysis is the manager-subordinate dyad. Other contemporary theories of leadership focus primarily on the manager's behaviour (e.g., McGregor's Theory Y, Blake \& Mouton's Managerial Grid, Fiedler's Contingency Theory, and Hersey \& Blanchard's Situational Leadership Theory), and typically prescribe a 'general leadership style' approach, appropriate for all situations (Gist, 1987). What these theories tend to ignore is the continuous reciprocal influence between manager and subordinate which Graen \& Scandura (1987) describe as a rolemaking process. Such reciprocal influence results in a unique relationship (termed an 'exchange') between a manager and each subordinate, characterized in terms of a relatively high or low quality. Thus in terms of the LMX theory, effective managerial leadership is expressed as an integrative effort between manager and subordinate, characterized by high mutual trust, interaction, support and the provision of both formal and informal rewards (i.e., high quality exchange) (Dienesch \& Liden, 1986). Conversely, ineffective leadership is characterized by low levels of trush, interaction, support and reward (i.e., a low quality exchange) (Dienesch \& Liden, 1986). In short, effective managerial leadership is described as being consistent with a participative or democratic management approach, rather than an autocratic approach. Indeed, a recent survey conducted with twenty groups of black, blue-collar workers ( $N$ $=128$ ) revealed that the workers want to be included in the 
decision-making process of their organizations, want to contribute their ideas as well as their skills, and want to be treated as equals (Alfred, 1991).

Generally, research has supported the LMX approach in the American and Japanese industrial environments (Dienesch \& Liden, 1986; Scandura, Graen, \& Novak, 1986). High quality manager-subordinate exchanges have been associated with improving subordinates' role development (Dansereau, Graen \& Haga, 1975), improved subordinate productivity (Graen, Novak, \& Sommerkamp, 1982b; Scandura \& Graen, 1984), and enhanced subordinate job satisfaction and involvement (Dansereau et al., 1975; Graen, Novak, \& Sommerkamp, 1982). Furthermore, high quality LMX was found to predict employee tumover better than an average leadership style approach (Graen, Liden \& Hoel, 1982a).

Notwithstanding such encouraging results, much research is needed to examine the host of factors that can influence the quality of the manager-subordinate dyadic relationship. Adopting an open-systems perspective, such factors could include individual inputs (e.g., personality, cognitive and attitudinal factors, as well as the behaviour of members of the dyad), group and organizational inputs (e.g., group norms, organizational policies, procedures and practices), and even environmental inputs (e.g., societal norms and laws, township stress and so forth). Not only must these factors be identified, but their relative importance must be assessed in order to avoid unwieldy and cumbersome theoretical models. Dienesch \& Liden's (1986) LeaderMember Exchange model simply refers to manager and subordinate 'characteristics' without specifying what such characteristics constitute. Moreover, how these characteristics interact is also unspecified. To attempt to identify and test the interrelationships between all possible variables affecting the quality of manager-subordinate dyadic relationships is far beyond the scope of a single study. However, the present article is an attempt to contribute to this area in a small way.

The aim of the present article is to examine the moderating effect of supervisory support (a component of leadership) on the relationship between subordinates' work locus of control (a personality variable) and their job involvement (an employee attitude associated with a high quality manager-subordinate dyadic relationship). Furthermore, the interrelationship between these variables is examined from the point of view of the subordinate. The importance of these psychological variables in the workplace and rationale for their hypothesised interaction is now discussed.

Job involvement is a complex concept based on cognition, action and feeling (Gergen, 1971). It is defined as a person's psychological identification with his or her specific job (Jans, 1982). Indeed, high job involvement reflects the importance of a person's job to his or her self-concept (Lawler \& Hall, 1970; Lodahl \& Kejner, 1965). Job involvement is an important employee attitude as it has been associated with effective participation in decision making (Rabinowitz \& Hall, 1977), high quality manager-subordinate relationships (Nunns et al., 1990), and, inversely with destructive interpersonal conflict (Nunns, 1987), employee tardiness, absenteeism, and labour turnover (Mitchell \& Larson, 1987). In terms of Graen's Leader-Member Ex- change model, job involvement is identified as an important outcome of the leadership process. In terms of this model, subordinates who experience high quality relationships with their managers enjoy greater communication, trust, influence in decision making and discretion with their managers than those who experience low quality exchanges (Kozlowski \& Doherty, 1989; Liden \& Graen, 1980). In return, the subordinate commits himself to greater degrees of involvement and commitment in the functioning of a department (Scandura \& Graen, 1984). Such greater involvement and commitment typically exceeds that required by the member's formal employment contract (Graen at al, 1982b).

Thus it is important to understand factors associated with employee job involvement. This is because high job involvement reflects, at least in part, the existence of an effective leadership process. Furthermore, feelings of relatively low or high job involvement can influence employee behaviour in ways which are either advantageous or deleterious to organizational welfare (Mitchell \& Larson, 1987).

A personality variable that has been used to explain employee job involvement is that of locus of control (Spector, 1982). Indeed, past research on this construct indicates that it correlated significantly ( $r$ 's $=.2 \&$.35) with job involvement (Reitz \& Jewell, 1979; Runyon, 1973). Rotter's (1966) concept of intemal-external locus of control describes the degree to which an individual believes that reinforcements are contingent on his or her own behaviour or are independent of it. Thus people who believe they have control over their own behaviour and destiny are referred to as 'internals', that is, they believe that at least some control over their lives resides within themselves. On the other hand, 'externals' believe that their behaviour and consequent reinforcements are determined by external agents, for example, by luck, fate, chance or powerful others (Joe, 1971). Thus 'internals' would experience greater work motivation and job involvement as they perceive themselves as having greater control over their work environment than their 'external' counterparts (Spector, 1982). More recently, domain-specific measures of the construct have been developed which have evidenced enhanced construct validity for the domain (Adler \& Weiss, 1988; Funtham, 1986; Spector, 1988).

Consequently, in this article the construct of work locus of control was used. This construct is concemed specifically with employees' loci of control within the work domain. Research indicates that the behaviour of internals and externals differ across organizational settings (see Spector, 1988). In general, intemals tend to believe that they can control the work environment through their behaviour, and thus attempt to exert more control than externals, provided that control is perceived to lead to desired outcomes or rewards (e.g., promotions, salary increases and career advancement) (Spector, 1982; Spector, 1988). Internals and externals respond differently to supervisory styles (Spector, 1982). Internals look to themselves for direction; externals look to others. For example, Runyon (1973) found internals to be more satisfied with a participative supervisory style than externals. This is because internals perceive themselves as being better able to control their own destinies under a 
participative, as opposed to a directive or autocratic supervisory style. Alternatively, externals were found to be more satisfied with directive supervision than internals (Runyon, 1973). Mitchell, Smyser \& Weed (1975) found internals to be more satisfied with a participative supervisory style than externals in a sample of 900 United States public utility employees. Furthermore, in the same study, extemals were found to be more satisfied than internals with a directive supervisory style. Cravens \& Worchel (1977) conducted a laboratory simulation of a repetitive job. This entailed subjects working on a manual task under a supervisor who used either a coercive or a non-coercive style to increase productivity. It was found that internals complied less with the coercive supervisor than did externals.

Thus, the research clearly indicates that a different supervisory style is appropriate depending on a subordinate's locus of control orientation. However, existing research on the interaction between leadership variables, and employee personality, has typically concentrated on directive versus participative supervisory styles (Runyon, 1973).

Supervisory support has been identified by various leadership theories as an important component of effective supervision (Likert, 1967; Steers \& Ponter, 1987; Taylor \& Bowers, 1972). However, there is a lack of research on supervisory support on the locus of control-employee attitude relationship.

Supervisory support is a component of social support (Howse, 1987). Social support can be offered by non-work and/or work-related sources. Non-work related sources include family members, friends and peers. Work-related sources include co-workers and supervisors (Howse, 1987). Likert's (1967) principle of supportive relationships states that an effective supervisor should be perceived by subordinates as a person whose primary concern is building and maintaining the subordinate's sense of personal worth. Furthermore, Likert (1967) states that the more often a supervisor is perceived as supportive by a subordinate, the greater will be the impact of the supervisor's behaviour on the subordinate's performance. House (1981) maintains that a supportive supervisor provides an employee with all the necessary resources (goods and services) and information required for coping with or solving problems that an employee may be facing. The provision of these various elements of supervisory support should ensure that task requirements are understood, situational constraints identified and adequate tools and resources provided.

Supportive supervisors ensure that employees understand their goals, and help and encourage employees who have difficulty in attaining goals rather than resorting to punishment. Thus, supervisory support is defined as a positive, constructive and helpful attitude toward employees (Locke \& Latham, 1984). However, as argued earlier, whereas such support and help would be of value to an employee with an external locus of control, the internal employee might well be annoyed by the same supervisory behaviour.

\section{Method}

\section{Subjects}

Questionnaires were distributed to 100 randomly selected non-managerial banking employees. Of the 100 distributed,
70- useable questionnaires were returned. The resulting sample comprised $70 \%$ females, $86 \%$ whites, and $79 \%$ English speaking ( $M$ age $=31, S D=11 ; M$ tenure [years] $=5$, SD $=6 ; 14 \%$ had no matric, $70 \%$ had matriculated, and $16 \%$ had post-matric qualifications). A letter was attached to the questionnaire setting out the purpose of the study and informing subjects that participation in the research was voluntary. Furthermore, subjects were not required to reveal their names and were asked to mail the completed question. naire directly to the researchers in prepaid addressed en velopes, to ensure confidentiality.

\section{Measures}

To assess the dimension of work locus of control, Spector's (1988) work locus of control scale was used. The scale is a 16-item measure of generalised control beliefs in work set tings, with low scores representing internality and high scores externality (Spector, 1988). Spector (1988) reports alpha coefficients of .85 for four samples ( $N$ 's $=86,41$, $101 \& 496$ ), and alpha's of .75 and .80 for a further two samples ( $N$ 's $=292 \& 160)$. In the study reported in the pretent article, the scale was found to demonstrate an acceptable level of reliability $(\alpha=.85)$. Spector $(1988)$ re ports significant correlations in the predicted direction with conceptually related constructs including job satisfaction (r's [256 \& 496] = -.68 \& -.43; $p<.05$ ) and Rotter's (1966) General Internal-External Locus of Control Scale (r's $[144,160 \& 496]=.57, .55, \& .49 ; p<.05$ ).

Supervisory support was measured by the 3-item supervisory support scale of the Taylor \& Bowers's (1972) Leadership Effectiveness scale. Taylor \& Bowers (1972) report an internal consistency measured by Cronbach's alpha of .94 for a sample of 325 work-groups in an oil refinery. Furthermore, Spearman-Brown reliability coefficients ranging from .90 to .93 were reported for 1048 subjects selected from seven types of organizations (Taylor \& Bowers, 1972). Test-retest reliability over a six month period of $r=$ .45 ( $p<.001$ ) was reported by Bluen (1986) for a South African sample. Cronbach's alpha was used to assess internal consistency reliability, which yielded a coefficient of 0.91 for this article.

The dimension of job involvement was measured by means of Jans' (1982) four-item scale (of which one is reverse scored). High scores reflect a high degree of job involvement (Jans, 1982). Alpha coefficients of .80 and .78 are reported by Jans (1982) while Nunns (1987) reports in alpha coefficient of .68 for a South African sample. Acceptable evidence for the reliability of this scale was demorstrated on the sample in the present article $(\alpha=80)$.

\section{Statistical analysis}

The statistical technique of moderated multiple regression was used to assess the moderating influence of supervisory support on the relationship between locus of control and job involvement. Before conducting the analysis, three assumptions underlying multiple regression were assessed (LewisBeck, 1980). Accuracy of measurement was established as all measures evidenced satisfactory internal consistency reliability. The existence of linear relationships between the 
independent and dependent variable, and between moderator and dependent variable was established by inspection of scatter plots. Absence of multicollinearity was demonstrated as the independent variables were not found to be significantly correlated to each other (Lewis-Beck, 1980).

Furthermore, any biographical variable significantly related to a dependent variable requires inclusion as a covariate in the moderated multiple regression analysis to reduce the possibility of spurious results (Bluen, 1986; Naele \& Lieberh, 1980). After testing for this, sex, age and tenure were included in the analysis as co-variates. Results of the regression analysis are presented in Table 1. After excluding $24 \%$ of the variance contributed by co-variates (i.e., sex $=7 \%$, age $=16 \%$ and tenure $=1 \%$ ), the interaction term of locus of control by supervisory support yielded a statistically significant result. This result indicated that supervisory support moderated the locus of control-job involvement relationship for the sample $(F=9.04, p<.05)$, accounting for a $9 \%$ increment in explained variance.

Table 1 Moderated multiple regression analysis of work locus of control (independent variable), supervisory support (moderator), and job involvement (dependent variable)

\begin{tabular}{lccccc}
\hline Variable & Beta & $\begin{array}{c}\text { Standard } \\
\text { error }\end{array}$ & $\mathbf{R}^{2}$ & $\begin{array}{c}\text { Changed } \\
\mathbf{R}^{2}\end{array}$ & $\begin{array}{c}\text { F. } \\
\text { value }\end{array}$ \\
\hline Covariates & & & & & \\
\hline Sex & -1.70 & 0.90 & 0.07 & 0.07 & $6.90^{*}$ \\
Age & -1.08 & 0.05 & 0.23 & 0.16 & $15.90^{* *}$ \\
Tenure & -0.19 & 0.11 & 0.24 & 0.01 & 0.75 \\
\hline
\end{tabular}

Main effects

\begin{tabular}{llllll}
\hline Locus of control (LC) & -0.29 & 0.12 & 0.27 & 0.03 & 2.67 \\
Supervisory support (SS) & -1.47 & 0.47 & 0.27 & 0.00 & 0.66 \\
\hline
\end{tabular}

Interaction effects

\begin{tabular}{llllll}
\hline LC $x$ SS & 0.03 & 0.01 & 0.36 & 0.09 & $9.04 * *$ \\
\hline$p<.05$ & & & & & \\
$* * p<.01$ & & & & & \\
\hline
\end{tabular}

The direction of the moderating role of supervisory support in the relationship between locus of control and job involvement is illustrated in Figure 1. The graph indicates that internals who have high supervisory support are less involved $(M=8.81)$ than internals who have low supervisory support $(M=9.85)$. On the other hand, externals who have high supervisory support are more involved in their jobs ( $M$ $=10.94)$ than extemals who have low supervisory support $(\mathbf{M}=10.00)$.

\section{Discussion}

Results reported in the previous section support the hypothesis that supervisory support moderates the relationship between work locus of control and job involvement. This finding is consistent with Lawler \& Hall's (1970) con-

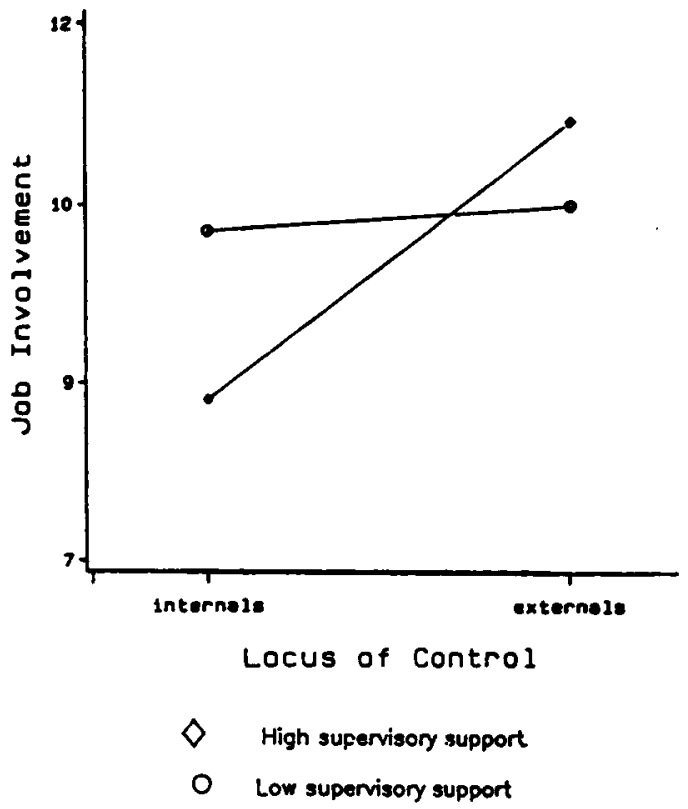

Flgure 1 Graphical representation of supervisory support moderating the work locus of control job involvement relation

clusion that people differ as a function of their personality in the degree to which they are likely to become involved in their jobs. In this regard, research has indicated a significant relationship between locus of control and job involvement, with internality resulting in greater job involvement (Reitz \& Jewell, 1979; Runyon, 1973). Also, supervisory style has been found to be significantly correlated with job involvement (March \& Simon, 1958; Siegal \& Ruh, 1973; White \& Ruh, 1973). More pertinent to the present article, supervisory support (an aspect of effective supervision) has been found to be positively related to job involvement (Anderson, 1964; Jones, James \& Bruni, 1975).

What then is the relevance of this fairly obvious finding? It stands to reason that people who prefer to rely on their own resources (i.e., employees with an internal locus of control orientation) become less involved with their jobs when their managers or supervisors insist on giving them unwanted assistance. Apart from the predictable response that one now has some empirical proof for the obvious, this finding relates to the broader issue of the need to explore the factors involved in effective manager-subordinate dyads. The result of the present article indicates that the interaction of work locus of control and supervisory support account for only a small, yet significant proportion (i.e., nine percent) of the total variance explained. This finding indicates that, in providing subordinates with supervisory support, a manager should take account of the internal external orientation of each subordinate.

However, this finding also suggests that there are a host of other factors that affect high quality dyadic exchanges. Indeed, in the role-making process, the manager and subordinate negotiate and reach agreement (either explicitly or implicitly) on a number of aspects of their relationship such as the extent of information shared and subordinate influence in decision making, the type of tasks assigned, the degree of the subordinate's autonomy and authority, and the extent of supervisory support, concem and trust provided by 
the manager (Graen \& Scandura, 1987; Kozlowski \& Doherty, 1989). This process is extremely complex involving many factors requiring research to identify them and establish their influence.

However, a number of limitations of the present article can be identified. Firstly, the sample comprised a greater propartion of women (i.e., 70\%) than men (i.e., 30\%). Secondly, the sample consisted of predominantly, White, English speaking subjects (i.e., 86\%). The greater proportion of White, English speaking women in the sample would limit the generalisability of the findings (Bluen, 1986). Clearly, additional research would be necessary to address this. Finally, letuers and questionnaires were administered in English and not necessarily in the home language of the subject. However, respondent questionnaires were scrutinized on their retum for response bias or obvious signs of the subject misunderstanding the instructions or questions in order to overcome such potential confounds.

Research has generally supported the efficacy of Graen's Leadership model in various overseas industrial environments (Dienesch \& Liden, 1986; Scandura et al., 1986). Based on the favourable research findings, this leadership approach is worthy of further research. For cxample, the concept of work locus of control represents a potentially useful personality variable for use in Dienesch \& Liden's (1986) Lcadership model and warrants further research. Given the acute shortage of managerial leaders in South Africa at present, research in this area could well be a fruitful endeavour.

In the present article only three variables, namely, work locus of control, supervisory support and job involvement were examined from the perspective of the subordinate. In order to understand more fully not only the variables involved (such as work values, other personality variables such as the Type $A$ and $B$ personality, organizational culture, policies and practices etc.), but also how they interact from both the manager's and the subordinate's perspective, a great deal of research is required.

\section{Acknowledgement}

The authors wish to thank Helen Mastrantonis for her invaluable comments on an earlier draft of this article.

\section{References}

Adler, S. \& Weigs, H.M. 1988. Recent developments in the study of personality and organizational behavior. In C. L. Cooper \& I. Robertson (Eds.). International review of industrial and organizational psychology. New York: Wiley, 337p.

Alfred, M. 1991. A view from the other side. Productivity SA, Vol. 17: 6-11.

Anderson, R. 1964. Activity preferences and leadership behavior of head nurses. J. of Nursing Research, Vol. 13: 239-243.

Bluen, S.D. 1986. Consequences and moderators of industrial relations stresses. Unpublished Doctoral Dissertation. Johannesburg: University of the Witwatersrand.

Chalmers, B. 1986. Integrated manpower development. In J. Barling. C. Fullagar, \& S. Bluen (Eds.). Behaviour in organizations: South African perspectives (2nd ed.). Johannesburg: McGraw-Hill, 924p.
Cogill, C. 1986. Leadership. In J. Barring, C. Fullagar, \& S. Bluen (Eds.). Behaviour in organizations: Soulh African per. spectives (2nd ed.). Johannesburg: McGraw-Hill, 924p.

Cravens, R.W. \& Worchel, P. 1977. The differential effects of rewarding and coercive leaders on group memebers differing in locus of control. J. Personality, Vol. 45: 150-168.

Dansereau, F., Graen, G., \& Haga, B. 1975. A vertical dyad linkage approach to leadership within formal organizations: $A$ longitudinal investigation of the role making process. Organizational Behavior and Human Performance, Vol. 13: 46-78.

Dienesch, R.M. \& Liden, R.C. 1986. Leader-member exchange model of leadership: A critique and further development. Academy of Management Review, Vol. 11: 618-634.

Funrham, A. 1986. Economic locus of control. Human Relations, Vol. 39: 29-43.

Gergen, K.J. 1971. The concept of self. New York: Holth Rinehart and Winston, 110p.

Gilbert \& Sullivan. 1879. The pirates of Penzarice. First performed in England, 1879.

Gist, M.E . 1987. Self-efficacy: Implications for organizational behavior and human resource management. Academy of Maragement Review, Vol. 12: 472-485.

Goldstein, A.P. \& Sorcher, M. 1974. Changing supervisor behavior. New York: Pergamon, 90p.

Graen, G. \& Scandura, T.A. 1987. Toward a psychology of dyadic organizing. Research in Organizational Behavior, Vol. 9: 175-208.

Graen, G., Liden, R.C., \& Hoel, W. 1982a. Role of leadership in the employee withdrawal process. J. of Applied Psychology. Vol. 67: 868-872.

Graen, G., Novak, M.A. \& Sommerkamp, P. 1982b. The effects of leader-member exchange and job design on productivity and satisfaction: Testing a dual attachment model. Organizational Behavior and Human Performance. Vol. 30: 109-131.

House, J.S. 1981. Social support and stress. Reading MA: Addison-Wesley, 156p.

Howse, D.A. 1987. The role of social support offerred by trade unions as a moderator of the stress-strain relationship. Unpublished MA Dissertation. Johannesburg: University of the Witwatersrand.

Jans, N.A. 1982. The nature and measurement of work involvement. J. Occupational Psychology, Vol. 55: 57-67.

Joe, V.C. 1971. Review of the internal-external control construct as a personality variable. Psychological Reports, Vol. 28: 619-640.

Jones, A.P., James, L.R. \& Bruni, J.R. 1975. Perceived leadership behaviour and employee confidence in the leader as moderated by job involvement. J. of Applied Psychology. Vol. 60: 146-149.

Kozlowski, S.W.J. \& Doherty, M.L. 1989. Integration of climate and leadership: Examination of a neglected issue. J. of Applied Psychology, Vol.74: 546-553.

Lawler, E.E. \& Hall, D.T. 1970. Relationship of the job characteristics to job involvement, satisfaction and intrinsic motivation. J. Applied Psychology, Vol. 54: 305-312.

Lewis-Beck, M.S. 1980. Applied regression: An introduction. London: Sage Publications, 75p.

Liden, R. \& Graen, G. 1980. Generalizability of the vertical dyad linkage model of leadership. Academy of Management Journal, Vol. 23: 451-465.

Liker, R. 1967. The human organisation. New York: McGrawHill, 258p.

Locke, E.A. \& Latham, G.P. 1984. Goal setting: A motivational uechnique that works. New Jersey: Prentice-Hall, 193p. 
Lodahl, T.M. \& Kejner, M. 1965. The definition and measurement of job involvement. J. of Applied Psychology, Vol. 49: 24-33.

March, J. \& Simon, H. 1958. Organisations. New York: Wiley, 262p.

Mitchell, T.R. \& Larson, J.R. 1987. People in organisations. An introduction to organisational behaviow (3rd ed). New York: McGraw-Hill, 602p.

Mitchell, T.R., Smyser, C.M., \& Weed, S.E. 1975. Locus of control: Supervision and work satisfaction. Academy of Management Journal, Vol. 18: 623-631.

Naele, J.M. \& Liebert, R.M. 1980. Science and behaviour (2nd ed.). New Jersey: Prentice Hall, 294p.

Nunns, C.G. 1987. The development and implementation of a behavioural measure of interpersonal conflict in industry. Unpublished Masters Dissertation. Johannesburg: University of the Witwatersrand.

Nunns, C., Ballantine, K., Burns, A., \& King S. 1990. Subordinate assessment of organisational leadership: Evaluation of the leader member exchange scale. Ergonomics SA, Vol. 2: 46-53.

Rabinowitz, S. \& Hall, D.T. 1977. Organisational research on involvement. Psychological Bulletin, Vol. 84: 265-288.

Reitz, H.J. \& Jewell, L.N. 1979. Sex, locus of control and job involvement: A six-country investigation. Academy of Management Journal, Vol. 22: 72-80.

Rotter, J.B. 1966. Generalised expectancies for internal versus external control of reinforcement. Psychological Monographs, Vol. 80: 1-28.

Runyon, K.E. 1973. Some interactions between personality variables and management styles. J. of Applied Psychology, Vol. 57: 288-294.
Scandura, T.A., Green, G.B. \& Novak, M.A. 1986. When managers decide not to decide automatically: An inveatigation of leader-member exchange and decision influence. J. of Applied Psychology, Vol. 71: 579-584.

Scandura, T.A. \& Graen, G.B. 1984. Moderating effects of initial leader - member exchange status on the effects of a leadership intervention. J. Applied Psychology, Vol. 69: 428-436.

Siegal, A.L. \& Ruh, R.A. 1973. Job involvement, participation in decision making, personal background and job behaviour. Organisational Bahoviour and Human Performance, Vol. 9: 318-327.

Spector, P.E. 1982. Behaviour in organisations as a function of employee's locus of control. Psychological Bulletin, Vol. 91: $482-497$.

Spector, P.E. 1988. Development of the work locus of control ccale. J. of Occupational Psychology, Vol. 61: 335-340.

Steens, P.M. \& Porter, L.W. 1987. Motivation and work behaviour (4th ed.). New York: McGraw-Hill, 595p.

Taylor, J.C. \& Bowers, D.G. 1972. Survey of organisations. Michigan: Institute for Social Research, University of Michigan, 64p.

Vecchio, R.P. \& Gobdel, B.C. 1984. The vertical dyad linkage model of leadership: Problems and prospects. Organizationd Behavior and Human Performance. Vol. 34: 5-19.

Vroom, V.H. 1983. Lesdership. In M.D. Dunnette (ed.). Handbook of industrial and organizational psychology. New York: Wiley, 1740p.

White, J.K. \& Ruh, R.A. 1973. Effects of personal values on the relationship between participation and job attitudes. Administrative Science Quarterly, Vol. 18: 506-514. 